\title{
Fpga'S in Mexican Agriculture; An Automation Technology to Increase Agricultural Productivity
}

\author{
Jaime Cuauhtemoc Negrete* \\ Independent Researcher and Technical writer graduated in Agrarian Autonomous Antonio Narro University, Mexico \\ *Corresponding Author: Jaime Cuauhtemoc Negrete, Independent Researcher and Technical writer graduated in Agrarian Autonomous \\ Antonio Narro University, Mexico.
}

Received: June 24, 2019; Published: October 15, 2019

DOI: 10.31080/ASAG.2019.03.0681

\begin{abstract}
Agricultural growth reduces poverty extreme, the concentration of poverty and profits inequality for society in general. On the other hand, the deficiency of dynamism in agricultural growth and absence of improvements in the productivity of land and work are a threat to attention in terms of rural poverty. Through the automation of agriculture with Fpga's, sensors can be installed where desired - in soil, water or agricultural machines - to collect data on goals related to inputs, such as soil moisture and crop health.. Depending on the context, farmers can choose to manually control connected devices or fully automate processes for whatever action is necessary. Automation of agriculture with Fpga's is vital in increasing production, since it allows to increase the cultivated area, successful cultivation techniques, lower costs and dignify human work, to carry out such technology the small farmer needs economic energy sources, practical, easy maintenance and operation, and whose working capacity and costs are appropriate to the size of the property. Being the purpose of this paper to review the application of the Fpga's to automation in Mexican agriculture to analyze your current situation and your perspectives to increase agricultural productivity and reduce the Mexican rural poverty. In Mexico, the application of the Fpga's is practically insignificant.It does not have the vitality that it is taking in other countries, it is essential to promote it to increase the productivity of small farmers.
\end{abstract}

Keywords: Agriculture; México; Internet of Things; Agricultural Technology; Rural Poverty

\section{Introduction}

Agricultural growth reduces poverty extreme, the intensity of poverty and income inequality for society in general. On the contrary, the lack of dynamism in agricultural growth and absence of improvements in the productivity of land and work are a threat to consideration in terms of rural poverty. Therefore, it is essential for the relief of rural poverty to solve the challenges facing the agricultural sector, including the increase the productivity of the workforce and ensure that agriculture small scale and the segment of rainfed crops are more competitive. world Bank (2009). There is a growing human population in the world which means there is need for an increase in food production.However, food production to feed this growing population is decreasing due to poor agricultural practices [39].
Through the automation of agriculture with Fpga's, sensors can be installed where desired - in soil, water or agricultural machines - to collect data on goals related to inputs, such as soil moisture and crop health. Depending on the context, farmers can choose to manually control connected devices or fully automate processes for whatever action is necessary. is vital in increasing production, since it allows to increase the cultivated area, improving cultivation techniques, lower costs and exalt human work, to transfer out such technology the small farmer needs economic energy sources, practical, easy maintenance and operation, and whose working capacity and costs are appropriate to the size of the property. Likewise [2632] proposes the application of new technologies in Mexican Agriculture such as Agricultural Mechatronics, Precision Agriculture, Precision Beekeeping, Precision Livestock,Arduino and Artificial Neural Network,Scada's, where the role of the agricultural automatization is of titanic importance. 
Summarizing, the only way to reverse the situation of extreme poverty in rural areas in Mexico is through the automation of agriculture with Fpga's the world there is a revolution in the application of this technology in agricultural production, livestock, aquaculture, apiculture,greenhouses, among others, this being the purpose of this paper to review the application of the through the automation of agriculture with Fpga's to Mexican agriculture to analyze your current situation and your perspectives to increase agricultural productivity and reduce the Mexican rural poverty.

A thorough search was made on the use of the internet in agriculture, using the databases of universities, research centers, scientific journals, the use of the same intertet being relevant.

\section{Literature Review}

FPGAs are programmable circuits formed by sets of cells matrix arrays. Each cell contains computational capacity to implement logical functions and perform routing for communication between them. 0 routing and the logical functions of cells are configurable via software.

The basic structure of an FPGA is composed of the following elements:

- Configurable Logic Block (CLB): Configurable logical unit;

- IOB (In / Out Block): input unitand output;

- $\quad$ SB (Switch Box): connection unit among the various CLBs;

- Routing channels: interconnect the connection units to form the network programmable interconnect.

FPGAs can be organized internally through the following settings:

- Symmetric matrix: has channels vertical and horizontal routing with great flexibility;

- Hierarchical PLD: block matrix interconnected logic systems that can be grouped each other;

- Row-based: logical blocks in layout with dedicated area for routing;
- Sea of gates: logical blocks of small complexity arranged in large number per unit area. There is no area dedicated to routing.

\section{Fpga's in Mexican Agriculture}

Duarte [7] focuses on testing if the monitoring of physiological process through a gas exchange methodology provides enough information to detect drought stress conditions in plants. The experiment consists of using a set of smart sensors based on Field Programmable Gate Arrays (FPGAs) to monitor a group of plants under controlled drought conditions.

Gonzalez [10] System based on FPGA-UC hybrid architecture for remote measurement of physiological variables in plants Development of a device to estimate transpiration remotely through an FPGA, a microcontroller and a programmable analogue arrangement in the field, also has a server with programs in java to obtain data sent wirelessly from the sensors.

Regalado [37] design and development of what will be a prototype of an integration platform for environmental variables sensors, based on FPGA.

Duarte [4] propose a new scheme for the control of greenhouses, where the use of wireless communications and a fusion of platformstechnologies include microcontrollers and field programmable gate arrays (FPGA) provide the tools necessary to modulate the administration of this system-

Millan [21,22] a real time phytomonitor that fuses many primary sensors is proposed in order to measure air temperature, leaf temperature, air relative humidity, and plant out relative humidity, carbon dioxide and ambient light. A field programmable gate array based unit is used to perform signal processing Algorithms.

Milan [23] developing a novel FPGA-based photosynthesis smart sensor. The smart sensor is capable of acquiring and fusing the primary sensor signals to measure temperature, relative humidity, solar radiation, $\mathrm{CO}$, air pressure and air flow. 


\begin{tabular}{|c|c|c|}
\hline [9] & $\begin{array}{l}\text { Presents an implementation of a fuzzy gain scheduling of proportionalintegral- derivative (PID) controller as } \\
\text { well as its comparison with a PID controller to adjust the fow rate of the carrier-chemical mix. Practical results } \\
\text { obtained with a test bench for sprayers have proven the efectiveness of the fuzzy gain scheduling of PID control- } \\
\text { ler proposed. }\end{array}$ & Brazil \\
\hline$[1]$ & $\begin{array}{l}\text { Presents comparison and utilization of resources, delay and minimum period with efficient data transmission } \\
\text { using SDI of FPGA. proposed new system,the data related to different parameters(humidity, temperature, dew } \\
\text { point, soil moisture and water level) will be collected and stored in flash memory. After this process, the data is } \\
\text { analyzed, displayed in LCD screen and the data is transmitted by SDI using different coding techniques. }\end{array}$ & India \\
\hline$[42]$ & $\begin{array}{l}\text { Designs a portable device that allows to determine the optimal moment of irrigation of crops. For this purpose, } \\
\text { a reflectance sensor connected to a microcontroller where a trained neural network runs. Although, the use of } \\
\text { these devices simplifies the design, It is proposed the realization of a specific architecture in order to reduce } \\
\text { costs, through the use of an FPGA }\end{array}$ & Argentina \\
\hline [19] & $\begin{array}{l}\text { Proposed and generated implementation of automation systems and spray control with national. Therefore, it } \\
\text { was defined, as a study case, the automation of the sprayer Autopropelido JACTO currently uses the electronic } \\
\text { controller spray gun JMC1000 / 4, uses microcontrollers to process their functions. This project, at this stage of } \\
\text { development, replaced several of the functions performed by microcontrollers replacing them and implementing } \\
\text { them in FPGAs. }\end{array}$ & Brazil \\
\hline [15] & $\begin{array}{l}\text { Integrate elements of embedded electronics from a case study of a microcontrollers, where it is proposed, aim- } \\
\text { ing to improve performance and hardware optimization, integration of the noblest functions of processing and } \\
\text { integration of various peripheral elements to microcontrollers in an FPGA (Field Programmable Gate Array). }\end{array}$ & Brazil \\
\hline$[5]$ & $\begin{array}{l}\text { Irrigation control is monitored through suitable moisture sensors and automatically pumps water when the need } \\
\text { arises through FPGA control logic thus requiring minimal human interventions. }\end{array}$ & India \\
\hline [42] & $\begin{array}{l}\text { The system collects meteorological data such as light radiation, humidity, temperature and wind speed; and opti- } \\
\text { mizes the climate in the greenhouse using a special algorithm that determines the movement of the greenhouses' } \\
\text { curtains. The project's innovation lies in the use of an FPGA (Field Programmable Gate Array) technology; }\end{array}$ & Greece \\
\hline$[34]$ & $\begin{array}{l}\text { Proposed idea about intelligent monitoring microenvironment of the crop field by using Universal Asynchronous } \\
\text { Receiver/Transmitter (UART) \& field programmable gate array (FPGA). }\end{array}$ & India \\
\hline$[33]$ & $\begin{array}{l}\text { A high-speed, low-cost, image-based sorting device was developed to detect and separate grains having slight } \\
\text { color differences or small defects. The device directly combines a complementary metal-oxide-semiconductor } \\
\text { (CMOS) color image sensor with a field-programmable gate array (FPGA) which was programmed to execute im- } \\
\text { age processing in real-time, without the need of an external computer. Spatial resolution of the imaging system } \\
\text { is approximately } 16 \text { pixels/mm. The system includes three image sensor/FPGA combinations placed around the } \\
\text { perimeter of a single-file stream of kernels, so that most of the surface of each kernel is be inspected. }\end{array}$ & USA \\
\hline$[5]$ & $\begin{array}{l}\text { Programmable Logic Devices (PLDs) present as a good option for the technology development and implemen- } \\
\text { tation, because PLDs allow fast development of prototypes and the design of complex hardware systems using } \\
\text { FPGAs (Field Programmable Gate Arrays) and Complex Programmable Logic Devices. }\end{array}$ & India \\
\hline$[6]$ & $\begin{array}{l}\text { Review on FPGA based water monitoring system related to water quality,river water parameters and agricultural } \\
\text { fields. }\end{array}$ & USA \\
\hline$[40]$ & $\begin{array}{l}\text { The part of the project presented here describes a node, consisting of a microcontroller PIC16F876, programmed } \\
\text { in such a way that it acquires the data of the sensors, for digital signals and organize them into a 128-bit packet } \\
\text { to transmit to the EC. The data is compiled by the EC which then controls the field points to be irrigated. Another } \\
\text { version of the node has been implemented in Java }{ }^{\circledR} \text { and uses the Femtojava microprocessor. This differs from PIC } \\
\text { because it is described in Java }{ }^{\circledR} \text { language, submitted to the Sashimi tool and prototyped in FPGA. }\end{array}$ & Brazil \\
\hline$[14]$ & $\begin{array}{l}\text { Present an irrigation control system based on an FPGA. Using RS-232 interface to communicate with a host com- } \\
\text { puter, the system receives irrigation commands from the decision making system and controls automatically the } \\
\text { irrigation of } 16 \text { greenhouses or pieces of field }\end{array}$ & China \\
\hline$[24]$ & $\begin{array}{l}\text { Development of a realtime remote monitoring system that acquires data from any kind of sensor to be transmit- } \\
\text { ted by radiofrequency to a computer with an interface module. This allows the sensing of large area fields with a } \\
\text { system capable of monitoring crop local environmental or physiological status; the data transmission and storage } \\
\text { in the computer is made in realtime. To design this device, the system on a chip approach was followed. Imple- } \\
\text { mentation was done in a field programmable gate array, which ensures a low cost. }\end{array}$ & India \\
\hline [36] & $\begin{array}{l}\text { Develop a system to sense and monitor real time agricultural environment using wireless sensor network that } \\
\text { is smart water distribution system. This is realized by network of FPGA based wireless sensor unit called field } \\
\text { module which will be spread across the field to cover area under irrigation. }\end{array}$ & India \\
\hline
\end{tabular}




\begin{tabular}{|c|c|c|}
\hline [13] & $\begin{array}{l}\text { FPGA implementation of irrigation control system is mainly focused on controlling the irrigation system at the } \\
\text { same time it will care the crop in all aspects for the benefit of agricultural system and provides sufficient irriga- } \\
\text { tion in particular field. It consists of different sensors that are interfaced with FPGA. The sensors will monitor the } \\
\text { field conditions, and the sensors information will be stored in memory }\end{array}$ & India \\
\hline [8] & $\begin{array}{l}\text { Presents the hardware design and implementation of a remote sensing system for humidity and temperature in } \\
\text { real time. The design based on using FPGA (Field Programmable Gate Array) for the hardware implementation of } \\
\text { the controller circuit and GSM (Global System for Mobile) for remote monitorin }\end{array}$ & Egypt \\
\hline [25] & $\begin{array}{l}\text { Presents the validation and filtering process for automagic agricultural weather stations (VIPMET), anew sta- } \\
\text { tion that is endowed with a real-time data filtering process to ensure validation of the acquired data. the se- } \\
\text { lected model has a } 266 \mathrm{MHz} \text { industrial real-timeprocessor for control, data logging, and analysis; a } 2 \mathrm{M} \text { gateSpar- } \\
\text { tan-3 FPGA (Field Programmable Gate Array); a } 10 / 100 \mathrm{Mb} \text { Ethernet port; a RS232 serial port for connection to } \\
\text { peripherals;and eight slots for } 10 \text { modules. }\end{array}$ & Colombia \\
\hline [38] & $\begin{array}{l}\text { Technological diagnostic process aimed at identifying the level of incorporation of programmable devices (micro- } \\
\text { controllers) and programmable logic devices (CPLD and FPGA) in the productive processes of the panela agroin- } \\
\text { dustrial sector, in the department of Boyacá. }\end{array}$ & Colombia \\
\hline [16] & $\begin{array}{l}\text { Design and implementation in a FPGA of a system for the calculation of vibration energy and its spectrum in a } \\
\text { pneumatic seeder. The objective is Integrate this implementation with other hardware modules and developed to } \\
\text { obtain, in a future work, a prototype for the inference of the position of the seed in the furrow. }\end{array}$ & Argentina \\
\hline [17] & $\begin{array}{l}\text { Model of the planting of a pneumatic seed drill, planting map implemented with reconfigurable logic using software } \\
\text { / hardware co-design techniques. With FPGA }\end{array}$ & Spain \\
\hline [18] & $\begin{array}{l}\text { Develop a smart sensor based monitoring system for agricultural environment using field programmable gate ar- } \\
\text { ray (FPGA) which comprised of wireless protocol, different types of sensors, microcontroller, serial protocol and } \\
\text { the field programmable gate array with display element }\end{array}$ & \\
\hline [20] & $\begin{array}{l}\text { Development of a real-time remote monitoring system that acquires data from any kind of sensor to be trans- } \\
\text { mitted by radiofrequency to a computer with an interface module, situated within a } 900 \mathrm{~m} \text { radius. FPGA-based } \\
\text { real-time remote monitoring system }\end{array}$ & \\
\hline$[11]$ & $\begin{array}{l}\text { Presents a solution for remote monitoring and sensing of differentagricultural parameters that effect the plant } \\
\text { growth and productivity.Hardware descriptive language has been used for the implementation ofproposed topol- } \\
\text { ogy on Field Programmable Gate Arrays. The hardware usedfor this purpose is an Altera board }\end{array}$ & Malasiya \\
\hline [41] & $\begin{array}{l}\text { Used a new technique to identify the pest \& type of disease in cotton plants. Images of leaves affected with some } \\
\text { disease will be done first with preprocessing. Images are then subject find Edge detection. Edge detected images } \\
\text { will be given to Advanced fuzzy Kmeans clustering for the segmentation. }\end{array}$ & India \\
\hline [12] & $\begin{array}{l}\text { FPGA design based implementation of a low cost advanced sowing machine controller that was built as a project } \\
\text { of a VLSI design using VHDL. The implemented sowing machine controller serves many purposes and is one of } \\
\text { the real and complex controller systems to revolutionize agriculture industry }\end{array}$ & India \\
\hline
\end{tabular}

Table 1: Fpga's use in World Agriculture.

\section{Conclusion}

From the literature review, the results the works are dominated predominantly by Asian authors although the origin changed as he found that the dominant country is India.In Mexico, the application of Fpga's to automation in to agriculture is virtually minimal.It does not have the dynamism that it is taking in other countries, it is necessary to promote it to increase the productivity of small farmers. Human capital to apply automation with FPGA to agriculture is guaranteed only has to be accentuated that is carried out inspiring students and graduates to effort on agricultural and cattle production.

\section{Bibliography}

1. Aparna YM., et al. "FPGA Implementation of an Agricultural Management System using Wireless Networks". International Journal of Computer Applications 105.18 (2014): 0975 - 8887.

2. Brahm Prakash Dahiya., et al. "Intelligent Monitoring the Crop Field Using Wireless Sensor Net Work Based on UART and FPGA Techniques". Progressive Agriculture 15.1 (2015): 71-76.

3. Carrillo-Serrano, R.V., et al. "FPGA-based fused smart sensor for real-time plant-transpiration dynamic estimation". Sensors 10.9 (2010): 8316-8331. 
4. Duarte Galván. “Carlos Sistema de control climático de bajo costo para invernadero basado en FPGA. M.Sc. Thesis. Universidad Autonoma de Queretaro (2011).

5. D Hanitha., et al. "FPGA Implementation of Automatic Irrigation and Pesticide Control System". International Journal of Reconfigurable and Embedded Systems (IJRES) 5.3 (2016):136140.

6. Divya Ramavat. "A review paper on FPGA based Water Monitoring Systems". Lake 2014: Conference on Conservation and sustainable Management of wetland Ecosystems in Western Ghats. USA. (2014).

7. Duarte-Galvan C., et al. "FPGA-Based Smart Sensor for Drought Stress Detection in Tomato Plants Using Novel Physiological Variables and Discrete Wavelet Transform". Sensors 14.10 (2014): 18650-18669.

8. El Medany WM. "FPGA Implementation for Humidity and Temperature Remote Sensing System”. Conference: Mixed-Signals, Sensors, and Systems Test Workshop, International (2008).

9. Felizardo K. R., et al. "Controlador Inteligente aplicado Em Um Sistema Depulverizacao Localizada de Agroquimicos Usando injecao AO Direta". Proceeding Series of the Brazilian Society of Applied and Computational Mathematics 1.1 (2013).

10. Gonzalez OCJ. "Sistema basado en arquitectura híbrida FPGAUC para la medición remota de variables fisiológicas en plantas". M.Sc. Thesis. Universidad Autónoma de Querétaro (2013).

11. Husni MI., et al. "Soil Moisture Monitoring Using Field Programmable Gate Array". Indonesian Journal of Electrical Engineering and Computer Science11.1(2018).

12. Kumar J., et al. "FPGA Based Advanced Sowing and Planting Equipment Controller Design". International Conference on Emerging Trends in Electronic and Photonic Devices and Systems (2009).

13. K Sindhu., et al. "FPGA Implementation of Irrigation Control System". International Journal of Scientific and Engineering Research 5.12 (2014).

14. Lai Z and Dai Y. "An Irrigation Control System Based on an FPGA". Second International Conference on Instrumentation and Measurement, Computer, Communication and Control (2012).
15. Marconato ES. "Automação e controle de pulverização em máquinas agrícolas". Trabalho de Conclusão de Curso (Bacharelado em Ciência da Computação) - Centro Universitário Eurípides de Marília - Fundação de Ensino Eurípides Soares da Rocha (2007).

16. Martínez R., et al. "Implementación en FPGA de un módulo para cálculo de la energía de vibraciones y su espectro en una máquina sembradora neumática". in Proc. III Congreso de Microelectrónica Aplicada, Rosario-Argentina 1-6. (2012).

17. Martinez RM. "Modelo del planteo de una sembradora neumática,mapa de siembra implementado con lógica reconfigurable utilizando tecnicas de codiseño software/hardware". Ph.D. Thesis. Universidad de Córdoba España. (2014).

18. Mathurkar SS., et al. "Smart sensorsbased monitoring system for agriculture using field programmable gate array". In: International Conference on Circuit, Power and Computing Technologies (ICCPCT)". IEEE (2014): 339-344.

19. Menezes D and Martins DdaS. "Automacao e Controle de Pulverizacao em Maquinas Agrícolas- REGRAD Revista de Graduação UNIVEM Regrad, Marília-SP 2.1 (2009): 23-34.

20. Mendoza-Jasso., et al. "FPGA-based real-time remote monitoring system". Computers and Electronics in Agriculture 49.2 (2005): 272-285.

21. Millan-Almaraz J. R., et al. "FPGA-based wireless smart sensor for real-time photosynthesis monitoring". Computers and Electronics in Agriculture 95 (2013): 58-69.

22. Millán Almaraz and Jesús Roberto "Desarrollo de tecnología de fitomonitoreo en tiempo real basado en FPGA Ph.D. Thesis". Universidad Autonoma de Queretaro (2011).

23. Millan-Almaraz JR., et al. "Diseño de un Sensor de Plantas Óptico para la Medición del NDVI Empleando un FPGA. Conference: XIII Workshop IBERCHIP At: Lima, Peru. (2007).

24. M Dinesh and P Saravanam. "FPGA Based Real Time MonitoringSystem for Agricultural Field”. International Journal of Electronics and Computer Science Engineering (2011): 1514-1519.

25. Molina-Martinez JM., et al. "VIPMET: New Real-Time Data Filtering-Based Automatic Agricultural Weather Station". Journal of Irrigation and Drainage Engineering 138.9 (2012). 
26. Negrete JC. "Mechatronics in Mexican Agriculture Current Status and Perspectives". SSRG International Journal of Agriculture and Environmental Science 2.3 (2015).

27. Negrete JC. "Automation of greenhouses in Mexico, current status and perspectives". Advance Research in Agriculture and Veterinary Science 3.2 (2016).

28. Negrete JC. "Precision Apiculture in Mexico, Current Statusand Perspectives". International Journal of Horticulture 7.10 (2017): 75-81.

29. Negrete JC. "Mechatronics and Precision Livestock Farming in Mexican Animal Production". Animal Review 4.1(2017): 1-7.

30. Negrete JC. "Precision agriculture in Mexico, current status,obstacles and strategies". International Journal of Horticulture 7.10 (2017): 75-81.

31. Negrete JC., et al. "Arduino board in the automation of agriculture in Mexico, a review". International Journal of Horticulture 8.6 (2018): 52-68.

32. Negrete JC. "SCADA'S in The Automation of Agriculture in Mexico, A Overview”. Acta Scientific Agriculture 2.7 (2018b).

33. Pearson T. "Hardware-based image processing for high-speed inspection of grains". Computers and Electronics in Agriculture 69.1 (2009): 12-18.

34. Prakash DB., et al. "Intelligent monitoring the crop field using wireless sensor network based on UART and FPGA techniques". Progressive Agriculture 15.1(2015): 76.

35. Prerana Sarwade., et al. "FPGA Based Real Time Monitoring System for Agricultural Field". International Journal of Electronics and Computer Science Engineering 3.3 (2017).

36. Priyanka J and Ranade SB. "Takale FPGA based Smart Water Distribution System using Wireless Sensor Network". International Journal of Advanced Research in Computer and Communication Engineering 5.6 (2016).

37. Regalado SJC., et al. "Implementacion en FPGA de Sensor de temperatura y humedad relativa para una futura plataforma de monitoreo Ambiental.Pistas Educativas, No. 120, noviembre 2016. México, Tecnológico Nacional de México/Instituto Tecnológico de Celaya”. Año 38 (2016).
38. Ruge R and IAy Pérez H WJ. "Diagnóstico tecnológico del uso de dispositivos programables en la industria boyacense. Caso de estudio: cadena agroindustrial de la panela". Revista Tecnura, 21.52 (2017): 130-147.

39. Sanda AR., et al. "Assessment of Irrigation Water Quality of the Jega Floodplains and Their Influence on Soil Properties". International Invention Journal of Agricultural and Soil Science 2.6 (2014): 94-98.

40. Souza G.P. Sistema Inteligente de Controle de Irriga ÇÃo (2003).

41. Srujana T., et al. "FPGA Implementation for Detection Disease on Cotton Plants Using Advanced Image Processing Algorithm". International Journal of Advanced Research in Electrical Electronics and Instrumentation Engineering 7.11 (2018).

42. Toloza J., et al. "Desarrollo de un prototipo de sistema portátil para la detección en tiempo-real de la necesidad de riego en cultivos de producción intensiva (2006).

43. Thirer N and Uchansky I. "An FPGA Based Computer System for Greenhouse Control Athens". Journal of Sciences2.1 (2015): 23-32.

\section{Volume 3 Issue 11 November 2019}

(C) All rights are reserved by Jaime Cuauhtemoc Negrete. 